\title{
Status of agricultural technology innovation in swampy land
}

\author{
Agus Hasbianto ${ }^{1 *}$, Sri Hartati ${ }^{1}$, Eni Siti Rohaeni ${ }^{2}$, and Muhammad Yasin ${ }^{3}$ \\ ${ }^{1}$ South Kalimantan Assessment Institute for Agricultural Technology, Indonesia \\ ${ }^{2}$ Indonesian Center for Agricultural Technology Assessment and Development, Indonesia \\ ${ }^{3}$ South Sulawesi Assessment Institute for Agricultural Technology, Indonesia
}

\begin{abstract}
This research was carried out to know the status of agricultural technology innovation used by farmers in lowland swamps and formulate policy recommendations for relevant stakeholders in land management for sustainable farming. The study was conducted using a survey method with a structured questionnaire and focus group discussion in 5 villages in Banjar Regency, South Kalimantan, with a total of 48 respondents. The results showed that the main commodity cultivated by farmers in lowlands was rice, where the agricultural technology innovation used was still limited to the use of superior varieties, while the use of other technologies was still low which resulted in low farm productivity. The causes of limited use of agricultural technology innovations include poorly organized land conditions and high-water levels in the land that make it difficult for equipment operations, narrow land area per farmer, limited infrastructure for mobility of agricultural machinery, limited capital, and low educational level of the main actors. Some of the proposed recommendations are improving cultivation technology, especially fertilization according to nutrient status and yield targets, land and water management, using mechanical devices as needed, and increasing the role of related institutions.
\end{abstract}

\section{Introduction}

Swampy land is potential as a source of food to support the current food supply and become agricultural land for the future. As the important part in agricultural development, the Indonesian government and community have put in many efforts to utilize swamp land as the Indonesia's future agricultural land and strengthening current food production. In general, the potential of swamp land as the important land in supporting sustainable food security of the nation can be seen from two aspects. First, the area of land that has not been utilized is still wide; and secondly, plant productivity is very likely to be increased through technology.

The area of swampland in Indonesia reaches 33.43 million ha and about 9.53 million ha of which is suitable for agriculture [26]. From this area, only 2.276 million ha have been utilized. So, there are still more than 7 million ha of swamp land that has not been utilized $[7,24]$. The vast swampland consists of tidal swamp land and marshland. The area of tidal swamp land reaches 20.12 million ha and 8.54 million ha of which is suitable for agriculture.

\footnotetext{
* Corresponding author: agushasbianto@gmail.com
} 
Meanwhile, the marshland area is around 13.31 million ha [3], with only 5\% had been utilized by farmer [13].

Some of the challenges in utilizing swampy land are high water levels, especially during the rainy season, low crop productivity, and the low level of education of most of the population. Marshland has an important role as a water catchment during the rainy season [1], where this area often experiences a very high-water flooding that cause marshland become not visible $[21,10]$. Therefore, farmers utilized swampy land only once in a year depend on the water level [28]. Furthermore, soil acidity should be put as one of limiting factors related to the availability of nutrients for crops [14].

The use of swamp land for agriculture is carried out to solve land problems and improve related infrastructure. Marshland can be used for agriculture by applying the right technology and management according to the characteristics of the land. [4,11]. Technologies that can be applied in swampy land include land management, soil and water management, soil amelioration and fertilization, adaptive varieties, pest/disease control, agricultural machineries $[12,16]$. In some areas, farmer institutions also need to be considered and developed so that they are able to support advanced farming $[13,15]$.

Lebak swamp land or marshland field has a high C-organic content and several essential elements in the moderate category $[6,18]$. Therefore, marshland field is generally categorized as fertile land. Farmers in lowland areas generally use small amounts of chemical fertilizers and in some areas do not use fertilizers at all. Farmers' habits in managing marshland field using simple equipment and improvised inputs are part of local wisdom that needs to be considered by policy makers.

Agriculture, especially rice crops in swampy areas, has been practiced for a long time by the community. However, agricultural development on these lands is still lagging behind compared to agriculture in dry land or tidal swamps. The same fact has been found by [27] in many swamp areas where farmers tend to grow local rice varieties In terms of technology, the Indonesian Agency for Agricultural Research and Development (IAARD) has produced various innovative technologies to increase the productivity of lowland swamp farming. However, the productivity of cultivated plants is still low. Hence, this research was carried out to know the status of agricultural technology innovation used by farmers in lowland swamps and formulate policy recommendations for relevant stakeholders in land management for sustainable farming.

\section{Materials and method}

This research was conducted from February to July 2019 in two sub-districts of Banjar Regency of South Kalimantan Province, namely Martapura and West Martapura subdistricts. These two locations were selected based on their location from the district capital, where Martapura represents the city area and West Martapura represents the remote area. The numbers of location were five villages: Sei Batang, Sei Batang Ilir, Sei Rangas Tengah, Sei Rangan Hambuku (West Martapura sub-district), and Bincau (Martapura sub-district).

The research used survey, interview, and focus group discussion (FGD) methods with a total of 48 respondents involved. The respondents consisted of farmers (30), field agricultural extension [12], researchers (4), and regional leaders (3). Structured questionnaires were used to collect data from each respondent. The FGD was held twice on different levels: sub-district level and province level. 


\section{Results and discussion}

\subsection{General information}

Banjar Regency plays an important role as one of rice production centers in South Kalimantan Province. Based on data released in the Banjar Regency in figures [18], the total marshlandfield in this Regency is 8.733 ha. This marshland is spread over six sub-districts, namely Martapura (7.2\%), East Martapura (16.8\%), West Martapura (26.6\%), Mataraman (13.3\%), Astambul (33.7\%), and Karang Intan (2.3\%). From this area, more than 8,000 ha of land is planted with rice and other crops, while the rest is still not cultivated. Most of the land is still planted with rice once a year and only 4.6 percent of them plant rice twice a year.

The results showed that the main commodity cultivated by farmers in lowlands was rice. All farmers in the research location planted local rice as the main crop in local rice-superior rice-vegetable planting patterns in a year. There are two main reasons support farmer decision in planting local rice: flavor [9] and higher price. The superior rice varieties were chosen as the second crops due to the appropriate water level for these crops. While vegetables are planted on bund land which usually located on a higher area.

Table 1. Rice productivity on marshland field in Banjar Regency

\begin{tabular}{|c|c|c|c|}
\hline Year & Harvested area (ha) & Production (ton) & Productivity (ton/ha) \\
\hline 2016 & 63.772 & 242.947 & 3.81 \\
\hline 2017 & 56.190 & 218.855 & 3.89 \\
\hline 2018 & 57.598 & 200.026 & 3,47 \\
\hline 2019 & 56.820 & 178.176 & 3.13 \\
\hline 2020 & 38.599 & 135.604 & 3.51 \\
\hline
\end{tabular}

Rice productivity in Banjar Regency is still low, less than $4.0 \mathrm{t} / \mathrm{ha}$ (Table 1). According to related respondents, extension officers, researchers, and policy makers, this lower productivity is influenced by the local variety that is dominant in marshland area. This situation also made rice productivity of Banjar Regency is much lower than rice productivity of the South Kalimantan Province. From figure 1 we may see the pattern of province is similar with the Banjar Regency which shows the strong influence of this regency as the rice production center. 


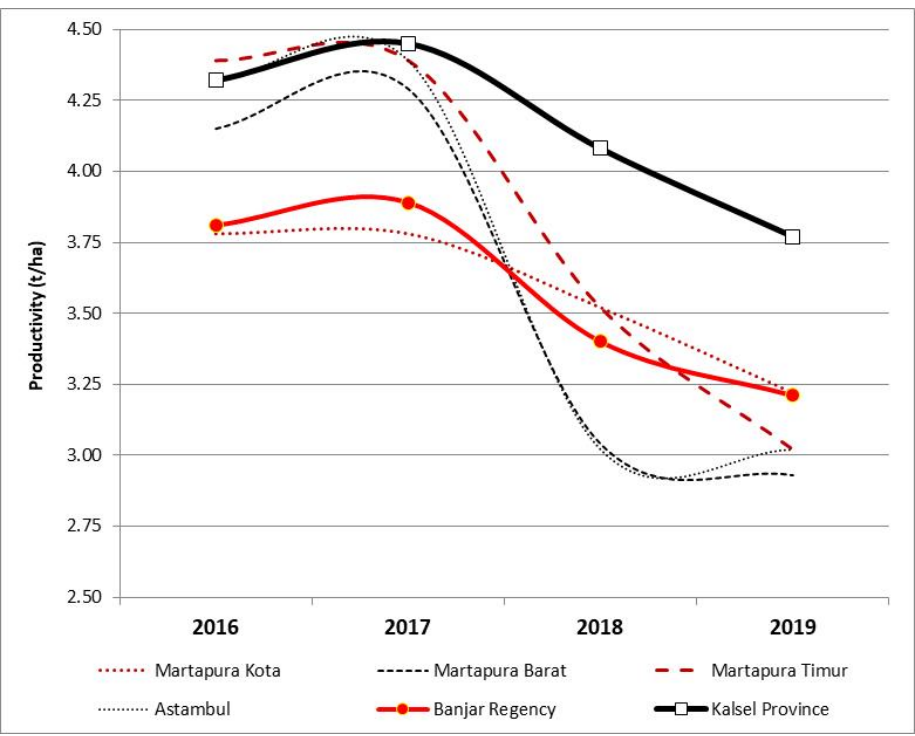

Fig. 1. Rice productivity of marshland area in Banjar Regency in the period of 2016-2019

\subsection{Farming system characteristic of surveyed location}

Farmer in West Martapura sub-district owned more land, 0.5-1.0 ha in average, compared to farmer in Martapura sub-district as the representative of a location near to city area with only 0.25 ha per farmer. For farmer in Bincau village who lived near the main city, they need to travel as long as $4,000 \mathrm{~m}$ to their land. There is various transportation mode can be used to reach the land such as bicycle, motorcycle, or jukung (wooden boat). During the rainy season, the water level on the field could reach 1.5 meter which is difficult to manage by farmer (Table 2).

Table 2. Land area and water depth of surveyed location

\begin{tabular}{|c|c|c|c|c|c|}
\hline Type of Data & $\begin{array}{c}\text { Sei Batang } \\
\text { Vill. }\end{array}$ & $\begin{array}{l}\text { Sei Batang } \\
\text { Ilir Vill. }\end{array}$ & $\begin{array}{l}\text { Sei Rangas } \\
\text { Tengah Vill. }\end{array}$ & $\begin{array}{c}\text { Sei Rangas } \\
\text { Hambuku } \\
\text { Vill. }\end{array}$ & Bincau Vill. \\
\hline $\begin{array}{l}\text { Land to } \\
\text { Home } \\
\text { distance (m) }\end{array}$ & 5,000 & 1,000 & 0,000 & 1,000 & 4,000 \\
\hline $\begin{array}{l}\text { Water level } \\
\text { (m) }\end{array}$ & $1.3-1.5$ & $1.3-1.5$ & $1.3-1.5$ & $1.3-1.5$ & 1.0 \\
\hline \multirow{2}{*}{$\begin{array}{l}\text { Land wide } \\
\text { (average, ha) }\end{array}$} & 1.0 & 1.0 & $0.5-1.0$ & 0.7 & 0.25 \\
\hline & $\begin{array}{l}\text { (95\% for rice, } \\
5 \% \text { for } \\
\text { vegetable) }\end{array}$ & $\begin{array}{l}\text { (93\% for rice, } \\
7 \% \text { for } \\
\text { vegetable) }\end{array}$ & $\begin{array}{l}\text { (93\% for rice, } \\
7 \% \text { for } \\
\text { vegetable) }\end{array}$ & $\begin{array}{l}\text { (94\% for rice, } \\
6 \% \text { for } \\
\text { vegetable) }\end{array}$ & $\begin{array}{l}(95 \% \text { for rice, } \\
5 \% \text { for } \\
\text { vegetable) }\end{array}$ \\
\hline
\end{tabular}

Rice is the main crop cultivated by farmer in all surveyed area. This commodity has been considered as the most adaptive crops in swampland [17,25]. However, the commodities cultivated by farmer in Bincau Village of Martapura sub-district are more diverse. Farmers use some of their land, especially a higher land to raise flower and vegetable (Table 3). The market demand for Jasmine flower is quite high in Banjar Regency as the raw material for health, social, and religion need [2,23]. Demand for vegetable fresh product is also high as this area is surrounding by housing and community activity centers. However, it is difficult 
to increase crops and flower production through expansion due to the limited availability of cultivated land. In this area, agricultural technologies to enhance plants and soil productivity are needed.

Table 3. Commodities and planting patterns in marshland of Banjar Regency, South Kalimantan Province

\begin{tabular}{|c|c|c|c|c|c|}
\hline Type of Data & $\begin{array}{l}\text { Sei Batang } \\
\text { Vill. }\end{array}$ & $\begin{array}{l}\text { Sei Batang } \\
\text { Ilir Vill. }\end{array}$ & $\begin{array}{l}\text { Sei Rangas } \\
\text { Tengah Vill. }\end{array}$ & $\begin{array}{l}\text { Sei Rangas } \\
\text { Hambuku Vill. }\end{array}$ & Bincau Vill. \\
\hline \multirow{5}{*}{ Commodities } & $\begin{array}{l}\text { Rice (local } \\
\text { varieties: } \\
\text { Siam Cantik, } \\
\text { Siam } \\
\text { Mayang, } \\
\text { Siam Saba, } \\
\text { Siam Adil; } \\
\text { and superior } \\
\text { varieties: } \\
\text { Ciherang, } \\
\text { Inpari 30) } \\
\end{array}$ & $\begin{array}{l}\text { Rice (local } \\
\text { varieties: } \\
\text { Siam Cantik, } \\
\text { Siam } \\
\text { Mayang, } \\
\text { Siam Adil; } \\
\text { and superior } \\
\text { varieties: } \\
\text { Ciherang, } \\
\text { Ipnari 30) }\end{array}$ & $\begin{array}{l}\text { Rice (local } \\
\text { varieties: } \\
\text { Siam Cantik, } \\
\text { Siam } \\
\text { Mayang, } \\
\text { Siam Adil; } \\
\text { and superior } \\
\text { varieties: } \\
\text { Ciherang, } \\
\text { Ipnari 30) }\end{array}$ & $\begin{array}{l}\text { Rice } \text { (local } \\
\text { varieties: Siam } \\
\text { Cantik, Siam } \\
\text { Mayang, Siam } \\
\text { Adil; and } \\
\text { superior } \\
\text { varieties: } \\
\text { Ciherang, } \\
\text { Ipnari 30) }\end{array}$ & $\begin{array}{l}\text { Rice (local } \\
\text { varieties: } \\
\text { Siam Cantik, } \\
\text { Siam } \\
\text { Mayang, } \\
\text { Siam Adil; } \\
\text { and superior } \\
\text { varieties: } \\
\text { Ciherang, } \\
\text { Ipnari 30) }\end{array}$ \\
\hline & $\begin{array}{l}\text { Fish (local } \\
\text { fish/spade) }\end{array}$ & $\begin{array}{l}\text { Vegetable } \\
\text { (eggplant, } \\
\text { cucumber, } \\
\text { chili, } \\
\text { pumpkin) }\end{array}$ & $\begin{array}{l}\text { Vegetable } \\
\text { (eggplant, } \\
\text { long bean, } \\
\text { chili) }\end{array}$ & $\begin{array}{l}\text { Vegetable } \\
\text { (eggplant, } \\
\text { chili) }\end{array}$ & $\begin{array}{l}\text { Vegetable } \\
\text { (eggplant, } \\
\text { long bean, } \\
\text { chili) }\end{array}$ \\
\hline & & $\begin{array}{l}\text { Fish } \\
\text { (karamba of } \\
\text { Parrot and } \\
\text { Gold fish) }\end{array}$ & $\begin{array}{l}\text { Livestock } \\
\text { (ducks) }\end{array}$ & $\begin{array}{l}\text { Livestock } \\
\text { (ducks) }\end{array}$ & $\begin{array}{l}\text { Livestock } \\
\text { (ducks) }\end{array}$ \\
\hline & & & $\begin{array}{l}\text { Fish } \\
\text { (karamba of } \\
\text { Parrot and } \\
\text { Gold fish) } \\
\end{array}$ & $\begin{array}{l}\text { Fish (local } \\
\text { fish/spade) }\end{array}$ & $\begin{array}{l}\text { Flower } \\
\text { (Jasmine) }\end{array}$ \\
\hline & & & & & $\begin{array}{l}\text { Fish } \\
\text { (karamba of } \\
\text { Parrot and } \\
\text { Gold fish) } \\
\end{array}$ \\
\hline \multirow{3}{*}{$\begin{array}{l}\text { Planting } \\
\text { patterns }\end{array}$} & $\begin{array}{l}\text { Local rice - } \\
\text { superior rice }\end{array}$ & $\begin{array}{l}\text { Local rice - } \\
\text { superior rice - } \\
\text { vegetable }\end{array}$ & $\begin{array}{l}\text { Local rice - } \\
\text { superior rice } \\
\text { - vegetable }\end{array}$ & $\begin{array}{l}\text { Local rice - } \\
\text { superior rice - } \\
\text { vegetable }\end{array}$ & $\begin{array}{l}\text { Local rice - } \\
\text { superior rice } \\
\text { - vegetable }\end{array}$ \\
\hline & & & $\begin{array}{l}\text { Ducks: } \\
\text { continuously } \\
\text { throughout } \\
\text { the year }\end{array}$ & $\begin{array}{l}\text { Ducks: } \\
\text { continuously } \\
\text { throughout the } \\
\text { year }\end{array}$ & $\begin{array}{l}\text { Ducks: } \\
\text { continuously } \\
\text { throughout } \\
\text { the year }\end{array}$ \\
\hline & & & & & $\begin{array}{l}\text { Flower: } \\
\text { continuously } \\
\text { throughout } \\
\text { the year }\end{array}$ \\
\hline
\end{tabular}

Most of the farmers use the product of their farming for consumption. Respondents in all village planted rice to fulfill their family need of staple food, except farmers in Bincau village who planted rice on a limited area of land use the entire product to be consumed by the family. The interview resulted that the main income for marshland farmers are livestock and vegetable, and in some area the caught fish to be sale to the nearer market. In all area, crop production faced competition for land use with another plant and housing. However, the threat came from housing development was higher and faster (Table 4). Thus, the opportunity 
to enhance crops productivity in the village located near to the city is likely slight due to the vast development of building.

Table 4. Product usage and factors influence food production in marshland field of Banjar Regency

\begin{tabular}{|c|c|c|c|c|c|}
\hline Type of Data & $\begin{array}{l}\text { Sei Batang } \\
\text { Vill. }\end{array}$ & $\begin{array}{l}\text { Sei Batang } \\
\text { Ilir Vill. }\end{array}$ & $\begin{array}{l}\text { Sei Rangas } \\
\text { Tengah Vill. }\end{array}$ & $\begin{array}{l}\text { Sei Rangas } \\
\text { Hambuku } \\
\text { Vill. }\end{array}$ & Bincau Vill. \\
\hline \multirow{5}{*}{ Product usage } & $\begin{array}{l}\text { Rice: for sale, } \\
\text { saving and } \\
\text { consumed }\end{array}$ & $\begin{array}{l}\text { Rice: for sale, } \\
\text { saving and } \\
\text { consumed }\end{array}$ & $\begin{array}{l}\text { Rice: for sale, } \\
\text { saving and } \\
\text { consumed }\end{array}$ & $\begin{array}{l}\text { Rice: for sale, } \\
\text { saving and } \\
\text { consumed }\end{array}$ & $\begin{array}{l}\text { Rice: for } \\
\text { consumed }\end{array}$ \\
\hline & $\begin{array}{l}\text { Fish: for sale } \\
\text { and } \\
\text { consumed }\end{array}$ & $\begin{array}{l}\text { Vegetable: } \\
\text { for sale }\end{array}$ & $\begin{array}{l}\text { Vegetable: } \\
\text { for sale }\end{array}$ & $\begin{array}{l}\text { Vegetable: } \\
\text { for sale }\end{array}$ & $\begin{array}{l}\text { Vegetable: } \\
\text { for sale }\end{array}$ \\
\hline & & $\begin{array}{l}\text { Fish: for sale } \\
\text { and } \\
\text { consumed }\end{array}$ & $\begin{array}{l}\text { Livestock: for } \\
\text { sale }\end{array}$ & $\begin{array}{l}\text { Livestock: for } \\
\text { sale }\end{array}$ & $\begin{array}{l}\text { Livestock: for } \\
\text { sale }\end{array}$ \\
\hline & & & $\begin{array}{l}\text { Fish: for sale } \\
\text { and } \\
\text { consumed }\end{array}$ & $\begin{array}{l}\text { Fish: for sale } \\
\text { and } \\
\text { consumed }\end{array}$ & $\begin{array}{l}\text { Fish: for sale } \\
\text { and } \\
\text { consumed }\end{array}$ \\
\hline & & & & & $\begin{array}{l}\text { Flower: for } \\
\text { sale }\end{array}$ \\
\hline $\begin{array}{l}\text { Factors } \\
\text { influence } \\
\text { food } \\
\text { production }\end{array}$ & $\begin{array}{l}\text { Work } \\
\text { motivation, } \\
\text { water } \\
\text { management, } \\
\text { crops } \\
\text { varieties, } \\
\text { farm road, } \\
\text { transportation } \\
\text { mode, Pest } \\
\text { management, } \\
\text { Technology } \\
\text { application }\end{array}$ & $\begin{array}{l}\text { Work } \\
\text { motivation, } \\
\text { water } \\
\text { management, } \\
\text { crops } \\
\text { varieties, } \\
\text { farm road, } \\
\text { transportation } \\
\text { mode, Pest } \\
\text { management, } \\
\text { Technology } \\
\text { application }\end{array}$ & $\begin{array}{l}\text { Work } \\
\text { motivation, } \\
\text { water } \\
\text { management, } \\
\text { crops } \\
\text { varieties, } \\
\text { farm road, } \\
\text { transportation } \\
\text { mode, Pest } \\
\text { management, } \\
\text { Technology } \\
\text { application }\end{array}$ & $\begin{array}{l}\text { Work } \\
\text { motivation, } \\
\text { water } \\
\text { management, } \\
\text { crops } \\
\text { varieties, } \\
\text { farm road, } \\
\text { transportation } \\
\text { mode, Pest } \\
\text { management, } \\
\text { Technology } \\
\text { application }\end{array}$ & $\begin{array}{l}\text { Work } \\
\text { motivation, } \\
\text { water } \\
\text { management, } \\
\text { crops } \\
\text { varieties, } \\
\text { farm road, } \\
\text { transportation } \\
\text { mode, Pest } \\
\text { management, } \\
\text { Technology } \\
\text { application }\end{array}$ \\
\hline $\begin{array}{l}\text { Competitor } \\
\text { commodity }\end{array}$ & Palm Oil & Palm Oil & Palm Oil & Palm Oil & Housing \\
\hline
\end{tabular}

Another common fact found during the research was the land status for farmer. All respondent from remote area stated that they owned the land and cultivated it for many years. Although they have acquired the land for generations, they have no desire to sell it due to the benefits they got from the land as the main source of family's income. On the other hand, the respondents who lived in the village near the city stated that their farming land belonged to someone else and their worked as the land cultivator (Table 5). These facts showed that farmer in remote area have a better chance to obtain more products from their land using technologies. The introduced technologies must be site-specific to give optimal benefit for farmers. In Table 5, we see some agricultural machineries are available on the village, but are mostly not suitable to the area and give less benefit to the users. 
Table 5. Land status and agricultural machineries in marshland field of Banjar Regency

\begin{tabular}{|c|c|c|c|c|c|}
\hline Type of Data & $\begin{array}{l}\text { Sei Batang } \\
\text { Vill. }\end{array}$ & $\begin{array}{l}\text { Sei Batang } \\
\text { Ilir Vill. }\end{array}$ & $\begin{array}{l}\text { Sei Rangas } \\
\text { Tengah Vill. }\end{array}$ & $\begin{array}{l}\text { Sei Rangas } \\
\text { Hambuku Vill. }\end{array}$ & Bincau Vill. \\
\hline $\begin{array}{l}\text { Farmer's } \\
\text { status }\end{array}$ & $\begin{array}{l}\text { As the land } \\
\text { owner and } \\
\text { also as } \\
\text { cultivator } \\
\text { (land owned } \\
\text { by another) }\end{array}$ & $\begin{array}{l}\text { As the land } \\
\text { owner and } \\
\text { also as } \\
\text { cultivator } \\
\text { (land owned } \\
\text { by another) }\end{array}$ & $\begin{array}{l}\text { As the land } \\
\text { owner and } \\
\text { also as } \\
\text { cultivator } \\
\text { (land owned } \\
\text { by another) }\end{array}$ & $\begin{array}{l}\text { As the land } \\
\text { owner and also } \\
\text { as cultivator } \\
\text { (land owned by } \\
\text { another) }\end{array}$ & $\begin{array}{l}\text { Mostly work } \\
\text { as land } \\
\text { cultivator } \\
\text { (owned by } \\
\text { another) }\end{array}$ \\
\hline $\begin{array}{l}\text { Agricultural } \\
\text { machineries }\end{array}$ & $\begin{array}{l}\text { Some } \\
\text { machines } \\
\text { managed by } \\
\text { farmer group: } \\
\text { tractor, water } \\
\text { pump, } \\
\text { thresher, } \\
\text { RMU }\end{array}$ & $\begin{array}{l}\text { Some } \\
\text { machines } \\
\text { managed by } \\
\text { farmer group: } \\
\text { tractor, water } \\
\text { pump, } \\
\text { thresher }\end{array}$ & $\begin{array}{l}\text { Some } \\
\text { machines } \\
\text { managed by } \\
\text { farmer group: } \\
\text { tractor, water } \\
\text { pump }\end{array}$ & $\begin{array}{l}\text { Some machines } \\
\text { managed by } \\
\text { farmer group: } \\
\text { tractor, water } \\
\text { pump, thresher }\end{array}$ & $\begin{array}{l}\text { Some } \\
\text { machines } \\
\text { managed by } \\
\text { farmer group: } \\
\text { tractor, water } \\
\text { pump, } \\
\text { thresher }\end{array}$ \\
\hline
\end{tabular}

The superior variety of rice is the widely known technology in marshland field. As explained previously, farmer planted superior variety after harvesting local variety. However, extension officers and researchers' respondents argue that farmer follow recommendation given by related parties. Therefore, the rice yield was still under expectation. All respondents including farmer believe that the use of technologies correctly will increase farming productivity. Therefore, technology dissemination through multi-media and strategies must continue to be encouraged.

Marshland is not regularly arranged as tidal swamp land. Fields in this area are poorly organized which caused by high-water level and land ownership. As shown in Table 5, marshland is owned by native inhabitants who generally inherit the land from generation to generation [8]. The water level of marshland is also influenced by the land management around the area which makes land management more difficult. Therefore, we found many farmers occupy narrow land to be used for farming.

Some agricultural technologies were found during survey in form of machineries. The most common agricultural machineries are hand tractor, water pump, and thresher. Hand tractors are rarely used by farmer due to the lack of supporting infrastructure such as farm road. It was difficult to mobilize tractors to all marshland field without hitting other paddy fields. Moreover, many farmers tend to use traditional tools like tajak in land preparation [5].

The unfavorable conditions of marshland farmers mentioned above are likely caused by the low level of their education. Referring to the research done by Nursyamsi et al. [13], the average education level of the marshland community is Junior High School. In some area, the education level of farmer is even lower. Aprini et al. [19] found that the education level of farmers in swampy land of South Sumatera is as low as primary school. This lower education level is also a great challenge in educate farmer to enhance their farming productivity. Nursyamsi et al. [13] concluded that the acceptance rate of farmer with lower education level to a new technology is also low. Therefore, increasing farming productivity through technology is not a simple thing, especially in marshland field.

Based on survey and interview result, we found some interesting agricultural practice of marshland farmer. In terms of the crops diversity, marshland farmers have implemented a multi cropping system in their farming. The paddy-vegetable is a common pattern used by farmer. In some areas, farmers also integrate livestock in their farming system. This system is suitable and profitable to be applied on the same agro-ecosystem. In terms of technology, farmer of marshland area has already known some agricultural innovation that can be used to enhance their production. The widely known technology is superior varieties of rice such 
as Ciherang, Mekongga dan Inpari 30. However, as write down in Table 6, farmers were still unaware to other technology components such as fertilization which was affected by their limited capital.

Some applicable advices and recommendations include planting superior varieties which have higher yield and early maturity, fertilization according to soil test and plant nutrient needs, operating suitable machineries, application of integrated pest management, and applying or keeping the crops-livestock integrated system in marshland field farming.

Table 6. Status of agricultural technologies on existing farming and some related recommendations

\begin{tabular}{|c|c|c|}
\hline Commodities & Existing Technologies (Farmer) & Recommendation \\
\hline \multirow[t]{5}{*}{ 1. $\quad$ Rice/Paddy } & $\begin{array}{l}\text { Varieties: local (Siam) and } \\
\text { Superior varieties (Ciherang, } \\
\text { Mekongga) }\end{array}$ & $\begin{array}{ll}\text { - } & \text { Superior varieties: higher } \\
\text { yield (Inpari 42) and early } \\
\text { maturity (Inpari 20) }\end{array}$ \\
\hline & $\begin{array}{l}\text { Fertilization: lower than } \\
\text { recommendation }(50 \mathrm{~kg} / \mathrm{ha} \\
\text { Urea, } 50 \mathrm{~kg} / \mathrm{ha} \text { TSP) }\end{array}$ & $\begin{array}{l}\text { Apply recommendation: } \\
\text { according to the results of } \\
\text { soil tests and plant nutrient } \\
\text { needs }\end{array}$ \\
\hline & $\begin{array}{l}\text { Agricultural machineries: } \\
\text { traditional tools (tajak, ani- } \\
\text { ani, etc) }\end{array}$ & $\begin{array}{l}\text { Machineries: modern } \\
\text { farming tools (specific for } \\
\text { marshland) }\end{array}$ \\
\hline & $\begin{array}{ll}- & \begin{array}{l}\text { Pest management: full } \\
\text { chemical application }\end{array} \\
\end{array}$ & $\begin{array}{l}\text { - } \quad \text { Pest management: integrated } \\
\text { pest management }\end{array}$ \\
\hline & $\begin{array}{l}\text { Planting system: } \\
\text { monoculture (Tegel } 25 \times 25 \\
\text { for superior var. and } 35 \times 35 \\
\text { for local var) }\end{array}$ & $\begin{array}{l}\text { Apply: jajar legowo }(2: 1 \text { or } \\
\text { 4:1) or tegel }\end{array}$ \\
\hline \multirow[t]{2}{*}{ 2. Vegetable } & - $\quad$ Fertilization: limited value & $\begin{array}{l}\text { Fertilization: according to the } \\
\text { results of soil tests and plant } \\
\text { nutrient needs }\end{array}$ \\
\hline & $\begin{array}{ll} & \text { Pest management: full } \\
\text { chemical application }\end{array}$ & $\begin{array}{l}\text { - } \quad \text { Pest management: integrated } \\
\text { pest management }\end{array}$ \\
\hline \multirow[t]{4}{*}{ 3. $\quad$ Livestock } & $\begin{array}{ll}\text { - } & \text { The most farmed: Serati dan } \\
\text { Peking ducks }\end{array}$ & $\begin{array}{ll} & \text { Recommended to raise } \\
& \text { laying ducks (Alabio) }\end{array}$ \\
\hline & $\begin{array}{l}\text { - The Days Old Ducks (DOD) } \\
\text { quality: uncertain }\end{array}$ & - $\quad$ Use standard DOD \\
\hline & $\begin{array}{l}\text { Feed: local feed mix without } \\
\text { nutrient standard }\end{array}$ & - $\quad$ Feed: use nutrient standard \\
\hline & $\begin{array}{l}\text { Environment sanitation: not a } \\
\text { concern }\end{array}$ & $\begin{array}{l}\text { Giving more concern on } \\
\text { environment sanitation }\end{array}$ \\
\hline 4. Farming model & - $\quad$ No-integration & $\begin{array}{ll}\text { - } & \text { Apply crops-livestock } \\
\text { integration }\end{array}$ \\
\hline
\end{tabular}

In paddy cultivation, the local variety can continue to be planted as the market preferences remain high but it is encouraged to apply fertilization recommendation for specific location. This recommendation may refer to soil test or any recommendation provided by relevant parties. IAARD has released an online version for this recommendation called "Katam Terpadu" which can be accessed by farmer in all area. In order to take advantage of limited time, the use of early maturity rice variety is recommended, for instance Inpari 20. Farmers used the swampy land for rice cultivation using paddy-vegetable planting pattern in a year. Market is a dominant factor that influences farmer decision in choosing variety. Farmers in 
all surveyed locations know the superior varieties but only few of them were willing to planting these varieties. Its

\section{Conclusion}

The main commodity cultivated by farmers in lowlands was rice, where the agricultural technology innovation used was still limited to the use of superior varieties, while the use of other technologies was still low which resulted in low farm productivity. The causes of limited use of agricultural technology innovations include poorly organized land conditions and high-water levels in the land that make it difficult for equipment operations, narrow land area per farmer, limited infrastructure for mobility of agricultural machinery, limited capital, and low educational level of the main actors. Some of the proposed recommendations are improving cultivation technology, especially fertilization according to nutrient status and yield targets, land and water management, using mechanical devices as needed, and increasing the role of related institutions.

\section{References}

1. B. M. Acreman, European Geosciences Union, 7, 3, (2003)

2. Hardiati and Suwasono. Buana Sains, 6, No. 2. P:115-126 (2006)

3. M. Noor. Marshland: ecology, utilization, and development (IAARD Press. Jakarta 2007)

4. M. Noor. Peatlands: development, conservation and climate change. (Gadjah Mada University Press, Yogyakarta, 2010)

5. I. Dewi, M.F. Syuaib, T. Mandang. Agricultural Engineering J., 25, 2, (2011)

6. Waluyo, S. Djamhari. Chemical properties of soil and land suitability in each typology of marshland field for rice cultivation: the case in Tanjung Elai Village of Ogan Komering Ilir Regency (2011)

7. Haryono. Swamplands: the future food barn for Indonesia, (IAARD Press. $2^{\text {nd }}$ Ed., 2012)

8. Haryono, M. Noor, H. Syahbuddin, M. Syarwani. Swamp land: research and development. (IAARD Press. Jakarta, 2013)

9. Nurnayetti and Atman. The Agricultural Technology Assessment and Development J., 16, 2, (2013)

10. B.A Margono, J.R.B. Bwangoy, P.V. Potapov, M.C. Hansen. Geo-spatial Information Sci., 17, 1, (2014)

11. D.S. Effendi, Z. Abidin, and B. Prastowo. Agricultural Innovation Development J., 7, 4 (2014)

12. K. Anwar. Amelioration and fertilization to increase soybean productivity on peatlands. Proceedings of the National Seminar on Agro-innovation Supporting Sustainable Superior Industrial Agriculture Based on Local Resources. Banjarbaru, August 2014. The South Kalimantan AIAT in corporation with The Government of South Kalimantan Province (2014)

13. D. Nursyamsi, M. Alwi, M. Noor, K. Anwar, E. Maftuah, I. Khairullah, I. Ar-Riza, S. Raihan, R.S. Simatupang, Noorginayuwati, A. Jumberi. General guidance on marshland field utilization, (IAARD Press. Jakarta, 2014)

14. M.P. Sirappa, M.L.J. Titahena. J Trop Soils, 19, 2, (2014)

15. E. Wildayana, A.S. Busri, M.E. Armanto. J. Wetlands Envir. Management, 4, 1, (2016)

16. A. Suryana. Agric. Res. Dev. J. 35, 2, (2016)

17. E. Wildayana, M.E. Armanto. Jurnal Ekonomi dan Studi Pembangunan, 9, 2, (2017)

18. M. Alwi. Potency and characteristic of marshland field (2017) 
19. N. Aprini, Sriati, N. Asmani, Maryadi. AGRIPITA J. 1, 1, (2017)

20. M. Alwi and Hairani. Al and Fe toxication in rice plants in acid sulphate tidal swamp land and efforts to overcome them (2018)

21. M.E. Armanto, E. Wildayana, B. Syakina. Dynamics, degradation and future challenges of wetlands in South Sumatra Province, Indonesia. E3S Web of Conferences 68, (2018)

22. The Statistic Indonesia Bureau of Banjar Regency. Banjar Regency in Figures 2018. (2018)

23. Bastiah, M. Rosni, Y. Azis. Frontier Agribisnis, 3, 4, (2019)

24. F. Syahputra, I.Y. Inan. Indonesian J. Socio Economics. 1, 2, (2019)

25. M. Chozin, S. Silalahi, Masdar, Sumardi. Akta Agrosia, 22, 1 (2019)

26. N. Wakhid, H. Syahbuddin. Agrin J. 23, 2 (2019)

27. J. Sudrajat, S. Gafur. Indonesian J. Geography. 52, 2, (2020)

28. Paiman, Ardiyanta, M. Ansar, I. Effendy, B.T. Sumbodo. Reviews in Agric. Sci. 8, (2020) 